\title{
Analysis of Operating Costs of Subsidies in the Field of Agriculture of EU Countries
}

\author{
J. Svoboda, J. Lososová, R. Zdeněk \\ Faculty of Economics, University of South Bohemia, České Budějovice, Czech Republic
}

\begin{abstract}
Anotace
Článek se zabývá srovnáním zemědělských dotací v členských státech EU v období 2004 - 2012 na základě databáze Farm Accountancy Data Network (FADN). Během sledovaného období byl zjištěn mírný nárůst provozních dotací s tím, že variabilita má klesající trend. Ve struktuře dotací je patrný jasný přechod k platbám odtrženým od produkce s výraznými rozdíly mezi původními a novými členskými státy (NMS). Pomocí shlukové analýzy byly členské státy rozděleny do skupin podle provozních dotací, celkové produkce a nákladů. Pomocí korelační analýzy byly hodnoceny vztahy mezi produkcí, náklady a provozními dotacemi přepočtené na hektar využívané zemědělské půdy. Zvýšení dotací se neprojeví ve vyšší produktivitě nákladů a jen velmi slabě se projeví ve vyšším podílu dotovaných nákladů.
\end{abstract}

\section{Klíčová slova}

Zemědělství, Společná zemědělská politika, provozní dotace, produkce, náklady.

\begin{abstract}
The article deals with comparison of agricultural subsidies in the member states of the EU in the period 2004-2012 based on the database Farm Accountancy Data Network (FADN). During the monitored period we found a slight increase of operational subsidies with the fact that variability shows a decreasing trend. In the structure of subsidies we can see a clear transition to payments separated from production with significant differences between original member states and new member states (NMS). With the help of cluster analysis the member states were divided into groups according to their operational subsidies, total production and costs. With the use of correlation analysis we assessed the relationships between production, costs and operational subsidies re-counted per ha of utilised agricultural area. The increase of subsidies will not occur in higher cost productivity and only very slightly will it occur in the higher share of subsidized costs.
\end{abstract}

\section{Keywords}

Agriculture, Common Agricultural Policy, operational subsidies, outputs, inputs.

Svoboda, J., Lososová, J. and Zdeněk, R. (2015) "Analysis of Operating Costs of Subsidies in the Field of Agriculture of EU Countries", AGRIS on-line Papers in Economics and Informatics, Vol. 7, No. 4, pp. 161 - 173, ISSN 1804-1930.

\section{Introduction}

The support of agricultural production in some form occurs in all world states. The reasons for this are the particularities in agricultural production which form externalities not appreciated by the market. The common agricultural policy (CAP) belongs to the most elaborated policies of the European Community. The common agricultural policy, introduced in 1962, acts as a partnership between the agriculture sector and society, between Europe and its farmers. Its main tasks are:
- to increase the productivity of agriculture so that the consumers have stable supplies of food at acceptable prices,

- to ensure that the EU farmers have an adequate living standard.

At present, fifty years later, further tasks have appeared:

- $\quad$ Securing food supplies - at a world-wide level food production will have to double to provide enough food for the 9 billion 
people of the estimated world population in 2050 .

- The change of climate and sustainable management of natural resources.

- Landscape conservation in the whole EU and viability preservation of the rural economy.

The common agricultural policy has three dimensions: market support, income support and rural development. These three dimensions are mutually connected and total sustainability of policy depends precisely on how well they complement one another (European Commission, 2014). Regarding the long history of the CAP, it is the policy which has been reformed on many occasions. However, an attempt for its fundamental reconstruction is represented only by reforms started in the $90 \mathrm{~s}$ and especially the reform of 2003. The main contribution of MacSharry's reform (1992) was the separation of subsidies from the level of production (decoupling), which resulted in the decrease of overproduction. The Community reduced guaranteed prices, which were compensated by way of direct payments determined on the basis of production range. Moreover, some compensations were paid out only on the basis of leaving a part of land to lie fallow.

Fischler's reform in 2003 introduced a single payment per farm. Therefore, farmers only get one payment instead of several. The paying out of direct payments is conditioned by keeping a set of legislative norms, the so called cross-compliance (19 rules for environmental protection, food safety and animal health). In 2008, the so called Health check was introduced In other words, a check-up of the CAP health state in 2008. Through a packet of four legislative documents, partial adjustments and smaller interventions into some CAP mechanisms were approved: direct payments and a modulation system, separating subsidies from production, changes in the field of common milk and dairy products market including the gradual elimination of the so called milk quotas. In 2013 the last change appeared, whose key principles are the change of the political paradigm (recognition of common provision of private and public goods), more effective and integrated structure of supportand bigger flexibility in fulfilling the aims of the common agricultural policy.

The four basic EU regulations of the new Common Agricultural Policy are published in the Official Journal of 20 December 2013. These four legislative texts reflect the political agreement between the European Commission, EU Member States Agriculture Ministers (in the Council) and the European Parliament. With these new rules, the vast majority of CAP legislation will be defined under four consecutive Regulations - a significant simplification - covering:

- Rural Development: Regulation 1305/2013

- "Horizontal" issues such as funding and controls: Regulation 306/2013

- Direct payments for farmers: Regulation $1307 / 2013$

- $\quad$ Market measures: Regulation 1308/2013

To ensure a smooth transition, Regulation 1310/2013 lays down certain transitional provisions as regards the application of the four basic regulations in the year 2014 (European Commission, 2013).

CAP is a common policy for all EU member states. It is run by the EU and is also financed from its budget. For the last 50 years the Common Agricultural Policy has been the European Union's most important common policy. This explains why traditionally it has taken a large part of the EU's budget, although the percentage has steadily declined over recent years. The CAP is financed by two funds which form part of the EU's general budget:

1. EAGF (The European Agricultural Guarantee Fund) primarily finances direct payments to farmers and measures regulating or supporting agricultural markets.

2. EAFRD (The European Agricultural Fund for Rural Development) finances the EU's contribution to rural development programmes (http://ec.europa.eu/agriculture/ cap-funding/index_en.htm).

CAP represents approximately $40 \%$ of the EU budget. This implies that this policy is one of a few fields in which the common policy is financed predominantly by the EU. Therefore, it is necessary to put the CAP budget into connection with total public expenses in the EU. In this case the given budget seems to be small - it represents only $1 \%$ of all public expenses in the EU. In 2014 it amounted to 58 billion euros. Furthermore, we need to point out that the share of the CAP's budget in the EU budget in the last 30 years has decreased considerably, from not quite $75 \%$ to approximately $40 \%$ (European Commission, 2014).

Problems regarding agricultural subsidies and predictions of their impacts on international markets and the EU are the topic of many studies, e.g. Fárek and Foltýn (2004), Donaldson et al. (1995), Beard and Swinbank (2001), Benjamin et al. (2006), Latruffe and Davidova (2007). Most 
foreign studies are directed at the impacts caused by the enlargement of the EU (Ciaian et al. 2007). An analyses of the impacts of the CAP on the new member states was carried out by e.g. Pokrivčák, Svinnen and Gorter (2003). Impacts of the CAP on the results of management of agricultural enterprises together with the reference to disparity of results according to the types of companies, natural conditions of management and economic prosperity were studied by Szabo and Grznár (2002).

Svatoš (1999) defines subsidies as the evaluation of the public sector, influencing the prices of products and services and prices of factors of production. Bečvářová et al. (2008) defines subsidies as transfers reflecting changes in the division of income which are not connected with the flow of goods and services. Grega (2005) defines them as an interference into the allocation powers of the price mechanism. Subsidies evoke discussions whether to subsidize agriculture or not. According to the opponents of subsidies, the problems with the economic situation are caused by bad management and subsidies into the agrarian sector are very high from the point of view of a taxpayer. Van Beers and Van den Bergh (2001) say that subsidies are introduced to support certain aims, changing in the course of time, and the impacts of subsidies are unpredictable. Subsidies lead to prices that convey fundamentally incorrect information about real costs relating to production, extraction or resource scarcity. Subsidies run the risk of favouring less profitable over more profitable firms, where profitability includes social costs. Therefore, subsidies should never be structural, but merely serve to guide transition periods.

The defenders of subsidies stress the particularity of the agrarian sector and the formation of social, environmental, consumer and other negative impacts on the dissolution of a higher number of agricultural companies. To which extent the removal of direct payments could influence the dynamics of land exploitation in Europe including impacts on structural changes and environment is discussed by e.g. Uthes et al. (2011), Acs et al. (2010), Offermann et al. (2009).

Reforms of the CAP are rather complicated and emerge in historical and political contexts and in the interaction of several institutional mechanisms, thus their results are not fully predictable (Moyer and Josling, 2002; Garzon, 2006; Swinnen, 2010). Erjavec and Erjavec (2015) detected that in the process of CAP reform decision-making, European institutions justified the CAP with a transformation of key discourses (productivist, multi-functional and neo-liberal) by emphasising the hugely popular environmental element while, at the same time, employing a strong productivist discourse at the level of measures and the budgetary distribution between the EU member states and farmers' groups. The prediction of impacts of changes in the CAP after 2013 is dealt with by Ciaian et al. (2014). They presume the strengthening of competition on the estate market and higher estate values, especially in the countries where subsidies will be balanced.

The aim of the article is the analysis of the policy of subsidies in the field of operational subsidies in the EU countries in years 2004 to 2012, which represents its comparison based on selected economic indicators. The objective was to find suitable connections and links among these indicators and operational subsidies.

\section{Materials and methods}

In the article we use calculations based on the database of selective research; The Farm Accountancy Data Network (FADN) in the EU. Standard output FADN is a set of indicators - the results of agricultural companies published officially per particular company types within FADN systems. The purpose of EU methodology is to enable the evaluation and comparison of economic results of agricultural companies in individual EU countries according to a single methodology, which is not influenced by divergences of tax accounting records (http://ec.europa.eu/agriculture/ricaprod/).

From many recorded indicators we have chosen those which are relevant for the given points at issue and are linked to operational subsidies. The indicators were:

- Total Utilised Agricultural Area in ha (SE 025).

- Total output (SE 131) - i.e. total output crop, livestock.

- $\quad$ Total Inputs (SE 270) - i.e. specific (direct) costs, overheads (e.g. energy, maintenance, repairs, fuel, etc.), depreciation and external factors (wages, rent, interest).

- Operational subsidies (SE 605).

FADN EU methodology within operational subsidies contains more types of subsidies. More detailed structure of operational subsidies was determined at the level of following groups: 
- Total subsidies on crops (Compensatory payments, Set aside premiums, Other crops subsidies)

- Total subsidies on livestock (Subsidies dairying, Subsidies other cattle, Subsidies sheep/goats, Other livestock subsidies)

- Environmental subsidies

- LFA subsidies

- Decoupled payment (Single Farm payment, Single Area payment, Additional aid)

- Others subsidies (Other RD subsidies, Subsidies on intermediate, consumption, Subsidies on external factors).

The draft of calculation of the basic indicators of economic activity results according to FADN EU methodology, which draws on the principle of creation and VAT difference, is illustrated by the following scheme (Fig. 1).

Considering the fact that the system of most paid out subsidies is directly dependent on the farm size, the indicators of total output, total costs and total operational subsidies were calculated per ha of Utilised agricultural area. Thus, the size of individual farms of given states is taken into consideration.

Based on these figures a cluster analysis could be carried out; a multi-variation statistic method which brings about a division of a big monitored group into smaller and more homogeneous ones. A similar method can be applied on the classification of EU member states according to the economic output of farms (Giannakis and Bruggeman, 2015). The process of clustering can be roughly divided into three categories: hierarchic, non-hierarchic and two-stage. Ward's method was used in this work. Ward's method joins two clusters A and B that minimize the increase in the sum of squares of error within a cluster, $\mathrm{I}_{\mathrm{AB}}$ (Rencher (2002), Řezanková, Húsek and Snášel (2009)),

$I_{A B}=\frac{n_{A} n_{B}}{n_{A}+n_{B}}\left(\overline{\mathbf{y}}_{A}-\overline{\mathbf{y}}_{B}\right)^{T}\left(\overline{\mathbf{y}}_{A}-\overline{\mathbf{y}}_{B}\right)$

where $n_{A}, n_{B}$ are the numbers of units in $A, B$; are centroids of $A$, and $B$, respectively. As distance function is used Eucliean distance between two vectors $x=\left(x_{1}, x_{2}, \ldots, x_{p}\right)^{T}$ and $y=\left(y_{1}, y_{2}, \ldots, y_{p}\right)^{T}$, defined as (Rencher, 2002)

$d(\mathbf{x}, \mathbf{y})=\sqrt{(\mathbf{x}-\mathbf{y})^{T}(\mathbf{x}-\mathbf{y})}$.

The aim of its assessment is the division of EU states into groups which enabled their clearer assessment. The commentary of these groups further contains basic descriptive statistical characteristics.

In another part, the links between defined indicators are described with the help of correlation and regressive analysis. Indicators related to utilized area value from FADN EU were further completed by relative indicators (total output/ operational subsidies, Operational subsidies/total costs, total output/total costs).

\section{Results and discussion}

\section{Comparison of selected FADN EU indicators in $\mathrm{EU}$ countries}

Before total assessment, it is suitable to point out how the EU enlarged with newly joining states

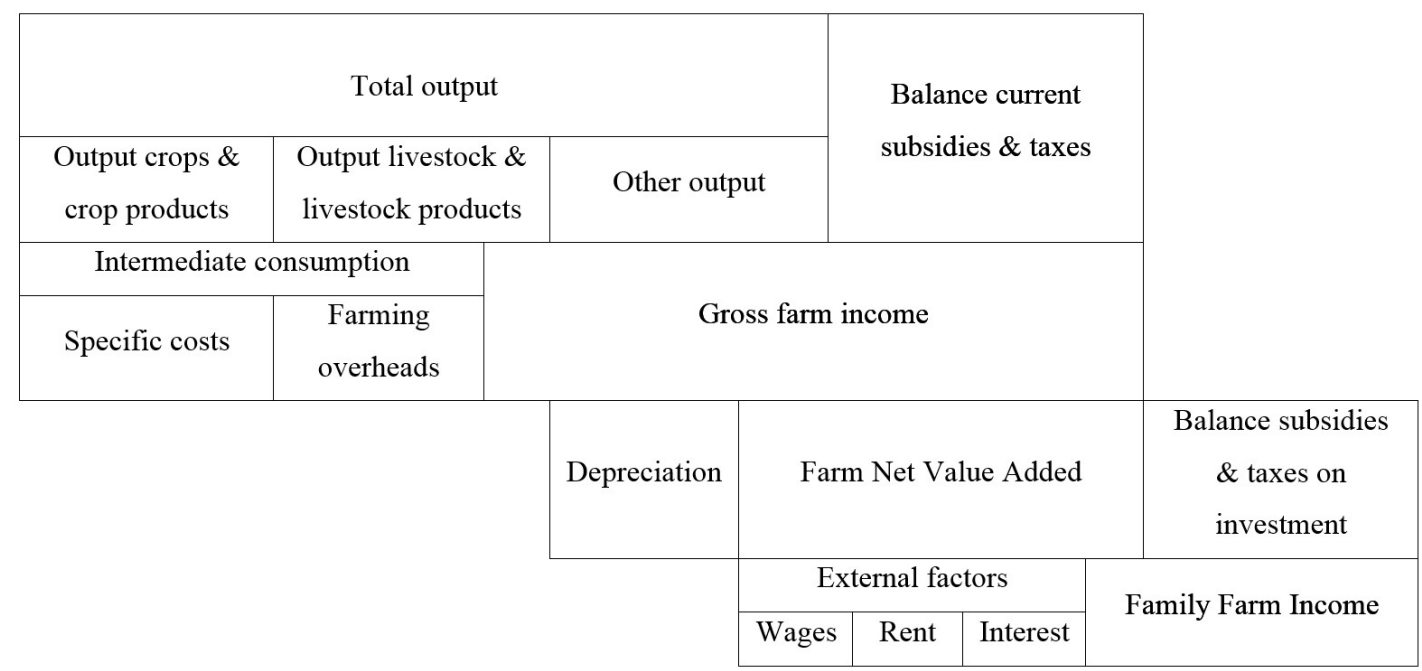

Source: FADN

Figure 1: Derivation of indicators of economic results according to FADN EU methodology. 
in the monitored period. 2004 was determined as the starting year of monitoring, i.e. the biggest EU enlargement by 10 new member states (NMS). During the monitored period Bulgaria and Romania also became members in 2007.

According to the utilized area value, the biggest EU farms are in Slovakia and the CR. Other countries with average sized farms over 100 ha are in Great Britain, Estonia and Sweden. Slovakia and the CR at the same time belong to countries with the biggest share of tenured land (table 1), i.e. landowners usually do not cultivate the land, but they rent it. In most East-Central European countries land was privatized by restitution. Land was given back to former owners or their successors within certain limits of size. In Czech Republic the restitution resulted in a severe fragmentation of ownership, sharply contrasting with the extreme land use concentration (Lososová, Zdeněk and Kopta, 2013).

The land rent growth, along with the growth in land prices, affects the majority of the Czech farms due to the high percentage of rented land. Despite the fact that these farms are trying to acquire the rented land, farmers fear that the land rent costs may negatively affect their farm plans in the near future. The land rent growth rate significantly exceeds the growth rate of profit, revenues and subsidies (Zdeněk, Lososová and Kopta, 2014). Regarding the average growth rate, it is possible to assume that land rent of the NMS is supposed to match the EU-15 (Lososová, Zdeněk and Kopta, 2013).

Viewing the development from 2004 it is obvious that the area value of an average company increased by more than $10 \%$ in most member states, and in the newly added Baltic countries and Poland. The biggest growth of the area value of an average company were in Lithuania, Greece, Denmark and Belgium. On the contrary, the decrease of the area value of an average company is apparent in Slovakia, Cyprus, Hungary, Malta and the CR. On comparison of the division of EU countries in 2004 and in 2012 (table 2 and 3), according to the extent of operational subsidies per ha

\begin{tabular}{|l|l|}
\hline Share of tenured land & Countries \\
\hline Up to $25 \%$ & Ireland (19.3) \\
\hline $25-50 \%$ & $\begin{array}{l}\text { Denmark (29.0); Spain (36.8); Italy (43.1); Latvia (47.7); Netherlands (41.3); Austria (28.1); } \\
\text { Poland (26.6); Portugal (26.5); Finland (33.9); Slovenia (35.0); United Kingdom (43.6) }\end{array}$ \\
\hline $50-75 \%$ & $\begin{array}{l}\text { Belgium (72.6); Cyprus (67.4); Germany (67.3); Greece (51.6); Estonia (62.2); Hungary (62.4); } \\
\text { Lithuania (53.7); Luxembourg (52.6); Romania (56.5); Sweden (54.1); EU (54.2) }\end{array}$ \\
\hline More than 75\% & Bulgaria (89.3); Czech Republic (82.6); France (87.7); Malta (82.1); Slovakia (95.0) \\
\hline
\end{tabular}

Source: FADN, own results

Table 1: Division of countries according to the share of tenured land in 2012 (in \%).

\begin{tabular}{|l|l|}
\hline Subsidy & Country \\
\hline Up to $200 € /$ ha & $\begin{array}{l}\text { Estonia (95); Slovakia (98); Lithuania (117); Latvia (122); Poland (129); Czech Republic (154); } \\
\text { Hungary (176); }\end{array}$ \\
\hline $200-400$ & $\begin{array}{l}\text { Spain (209); Portugal (225); United Kingdom (281); EU (305); Sweden (324); Netherlands (333); } \\
\text { France (351); Italy (363); Denmark (367); Ireland (381); Germany (388); Belgium (396) }\end{array}$ \\
\hline $400-600$ & Slovenia (461); Luxembourg (504); Cyprus (514) \\
\hline More than 600 & Austria (610); Greece (658); Finland (889); Malta (2 289) \\
\hline
\end{tabular}

Source: FADN, own results

Table 2: Division of EU countries according to the extent of operational subsidy in $€ /$ ha in 2004.

\begin{tabular}{|l|l|}
\hline Subsidy & Country \\
\hline Up to 200 €/ha & Lithuania (183); Latvia (190); Bulgaria (191); Romania(194); Estonia (196) \\
\hline $200-400$ & $\begin{array}{l}\text { Spain (244); United Kingdom (263); Slovakia (272); Portugal (281); Poland (299); Hungary (328); } \\
\text { EU (341); France (361); Czech Republic (364); Denmark (383); Sweden (385) }\end{array}$ \\
\hline $400-600$ & $\begin{array}{l}\text { Germany (409); Italy (420); Ireland (427); Belgium (515); Cyprus (537); Austria (574); } \\
\text { Netherlands (578) }\end{array}$ \\
\hline More than 600 & Luxembourg (613); Slovenia (626); Greece (710); Finland (921); Malta (1 102) \\
\hline
\end{tabular}

Source: FADN, own results

Table 3: Division of EU countries according to the extent of operational subsidy in $€ /$ ha in 2012. 
of Utilised agricultural area, the shift of the CR from the position where subsidies reached only $50 \%$ of EU average to subsidies $7 \%$ higher than the average, is apparent. The biggest increase of operational subsidies in the monitored period happened in Slovakia, the CR and Poland. These countries gained more than double the subsidies per ha of Utilised agricultural area in 2012 than in 2004, although neither Slovakia nor Poland have reached the EU average so far. In 2004 subsidies exceeded the EU average only in Slovenia (from the newly added countries). Contrary to 2004, a decrease of subsidies per ha occurred only in Malta, Austria and Great Britain.

However, a substantial problem is also the structure of individual subsidies (table 4). Years 2004 and 2012 are presented here again to get a basic comparison. Unambiguously, this implies a diversion from the support of particular crops or animals (vegetable or animal production), whose share (in total operational subsidies) decreased in average from about $63 \%$ in 2004 to not quite $8 \%$ in 2012 , to the so-called decoupling, where the proportion is in fact the opposite, i.e. from about $9 \%$ in 2004 to about $60 \%$ in 2012 . The other types of subsidies can be considered as relatively stable - environmental subsidies $10.4 \%$ and $13 \%$, LFA subsidies $10.5 \%$ with a slight drop to $8.8 \%$ and other subsidies $69 \%$ and $10 \%$.

The starting amount of subsidies of vegetable and animal production were in the competence of given states with their political decisions respecting the particularities of their countries and determined priorities.

The starting extent of direct payments (subsidies

\begin{tabular}{|c|c|c|c|c|c|c|c|c|c|c|c|c|}
\hline \multirow[t]{2}{*}{ State } & \multicolumn{2}{|c|}{$\begin{array}{l}\text { Total subsidies } \\
\text { on crops }\end{array}$} & \multicolumn{2}{|c|}{$\begin{array}{c}\text { Total subsidies } \\
\text { on livestock }\end{array}$} & \multicolumn{2}{|c|}{$\begin{array}{c}\text { Environmental } \\
\text { subsidies }\end{array}$} & \multicolumn{2}{|c|}{ LFA subsidies } & \multicolumn{2}{|c|}{$\begin{array}{c}\text { Decoupled } \\
\text { payments }\end{array}$} & \multicolumn{2}{|c|}{ Other subsidies } \\
\hline & 2004 & 2012 & 2004 & 2012 & 2004 & 2012 & 2004 & 2012 & 2004 & 2012 & 2004 & 2012 \\
\hline Belgium & 27.5 & 0.5 & 51.5 & 14.8 & 4.7 & 7.6 & 1.8 & 1.9 & 0.0 & 63.7 & 14.5 & 11.6 \\
\hline Bulgaria & - & 3.7 & - & 7.5 & - & 5.3 & - & 3.9 & - & 65.6 & - & 14.0 \\
\hline Cyprus & 54.6 & 0.0 & 32.7 & 9.0 & 0.0 & 22.1 & 0.0 & 8.6 & 12.7 & 53.5 & 0.0 & 6.8 \\
\hline Czech Republic & 21.4 & 0.2 & 8.1 & 2.5 & 6.8 & 14.5 & 14.9 & 9.1 & 35.5 & 58.3 & 13.3 & 15.3 \\
\hline Denmark & 74.3 & 0.1 & 18.8 & 1.3 & 3.9 & 2.1 & 0.1 & 0.1 & 0.0 & 90.3 & 2.9 & 6.0 \\
\hline Germany & 56.2 & 0.4 & 18.8 & 0.3 & 10.6 & 9.1 & 5.4 & 4.0 & 0.0 & 77.1 & 9.1 & 9.1 \\
\hline Greece & 72.1 & 9.1 & 18.2 & 1.3 & 0.1 & 1.5 & 7.9 & 6.7 & 0.0 & 73.6 & 1.6 & 7.7 \\
\hline Spain & 65.5 & 6.9 & 27.0 & 8.0 & 1.3 & 5.7 & 2.8 & 3.8 & 0.0 & 73.3 & 3.4 & 2.3 \\
\hline Estonia & 17.4 & 0.0 & 13.2 & 2.5 & 31.3 & 27.8 & 9.0 & 4.8 & 25.5 & 47.6 & 3.5 & 17.3 \\
\hline France & 59.0 & 3.9 & 26.2 & 9.5 & 6.1 & 4.4 & 4.8 & 5.5 & 0.0 & 72.2 & 3.9 & 4.5 \\
\hline Hungary & 32.8 & 4.3 & 9.2 & 5.0 & 0.1 & 17.2 & 0.2 & 0.8 & 35.7 & 62.3 & 22.0 & 10.4 \\
\hline Ireland & 7.8 & 0.0 & 62.1 & 1.4 & 14.0 & 14.5 & 13.5 & 9.6 & 0.0 & 72.1 & 2.6 & 2.5 \\
\hline Italy & 74.7 & 2.6 & 14.9 & 1.4 & 5.6 & 10.3 & 2.2 & 5.1 & 0.0 & 76.3 & 2.6 & 4.3 \\
\hline Lithuania & 22.3 & 0.0 & 11.0 & 4.1 & 0.0 & 1.8 & 27.3 & 9.6 & 27.4 & 63.8 & 12.0 & 20.7 \\
\hline Luxembourg & 17.7 & 0.0 & 29.6 & 0.1 & 20.5 & 20.2 & 25.7 & 20.2 & 0.0 & 44.3 & 6.4 & 15.2 \\
\hline Latvia & 28.3 & 0.2 & 19.2 & 13.1 & 8.0 & 15.8 & 19.6 & 13.1 & 14.1 & 37.6 & 10.8 & 20.2 \\
\hline Malta & 10.1 & 9.9 & 58.1 & 0.0 & 1.9 & 8.6 & 9.3 & 20.6 & 0.0 & 60.2 & 20.6 & 0.6 \\
\hline Netherlands & 38.7 & 0.0 & 43.4 & 0.7 & 13.8 & 9.4 & 0.0 & 0.4 & 0.0 & 77.8 & 4.1 & 11.7 \\
\hline Austria & 23.1 & 2.4 & 18.5 & 4.0 & 40.7 & 34.6 & 13.8 & 14.5 & 0.0 & 36.6 & 4.0 & 8.0 \\
\hline Poland & 54.8 & 1.5 & 0.1 & 0.9 & 0.2 & 7.4 & 1.1 & 7.0 & 35.9 & 58.6 & 7.9 & 24.6 \\
\hline Portugal & 34.6 & 8.8 & 35.8 & 19.2 & 13.6 & 10.1 & 12.8 & 15.1 & 0.0 & 42.6 & 3.1 & 4.2 \\
\hline Romania & - & 0.7 & - & 5.2 & - & 3.1 & - & 1.3 & - & 61.4 & - & 28.3 \\
\hline Finland & 23.1 & 6.0 & 33.5 & 20.1 & 19.5 & 21.9 & 21.2 & 26.3 & 0.0 & 22.9 & 2.8 & 2.8 \\
\hline Sweden & 41.8 & 0.0 & 27.7 & 4.3 & 21.4 & 25.8 & 5.5 & 8.5 & 0.0 & 60.0 & 3.7 & 1.4 \\
\hline Slovakia & 11.4 & 0.0 & 3.4 & 3.0 & 0.0 & 10.1 & 36.4 & 18.4 & 43.3 & 62.8 & 5.4 & 5.6 \\
\hline Slovenia & 14.0 & 0.2 & 27.0 & 3.9 & 28.9 & 23.1 & 22.1 & 15.3 & 0.0 & 44.5 & 8.0 & 13.1 \\
\hline United Kingdom & 36.3 & 0.0 & 45.2 & 0.8 & 7.5 & 17.2 & 6.1 & 3.2 & 0.0 & 77.3 & 5.0 & 1.5 \\
\hline Average & 36.8 & 2.3 & 26.1 & 5.3 & 10.4 & 13.0 & 10.5 & 8.8 & 9.2 & 60.6 & 6.9 & 10.0 \\
\hline
\end{tabular}

Source: FADN, own results 
on crops, subsidies on livestock, decoupled payments) for NMS was determined at $25 \%$ in 2004 with 5\% growth up to 2007 (40\%) and further $10 \%$ annual growth with the possibility of paying off from national resources right to $30 \%$. Table 5 illustrates a gradual start of direct payments on the example of the CR and a real share of direct payments per ha of Utilised agricultural area towards the EU average (including NMS) and towards Germany's average. Direct payments in NMS (except Malta and Cyprus) reached the EU average in the monitored period only in Slovenia.

Average operational subsidies per ha of Utilised agricultural area in the EU from 2004 make $333 € /$ ha and the trend is slightly growing. The median shows an average growth rate of $1 \%$ annually, it grew from $351 € /$ ha in 2004 to $383 € /$ ha in 2012 . Variability of subsidies is the lowest in comparison with output and costs and shows a decreasing trend. The highest variation coefficient was $112 \%$ in 2008 and the lowest in 2011 and 2012, when its value was 53\%. The range of subsidies has a dropping trend in time, values of minimum and maximum draw near each other during the monitored period.

According to operational subsidies per ha the EU, states can be also divided into 6 groups (figure 2):

Group 1 (Belgium, Holland, Luxembourg, Cyprus, Austria, Slovenia) operational subsidies per ha are above average - $540 € /$ ha, which is $162 \%$ of the EU average. The output $(222 \%)$ and costs $(234 \%)$ are above average too.

Group 2 (France, Sweden, Italy, Denmark, Germany, Ireland) is characterized by slightly above-average operational subsidies per ha of utilised agricultural area. Subsidies reach $116 \%$ of the EU average and are $386 € /$ ha. The output is $121 \%$ and costs are $140 \%$ of the EU average.

Group 3 (Greece, Finland) has significantly aboveaverage subsidies - $884 € /$ ha, which is $266 \%$

\begin{tabular}{|l|c|c|c|c|c|c|c|}
\hline Year & 2004 & 2005 & 2006 & 2007 & 2008 & 2009 & 2010 \\
\hline Share of direct payments from the EU & $25 \%$ & $30 \%$ & $35 \%$ & $40 \%$ & $50 \%$ & $60 \%$ & $70 \%$ \\
\hline $\begin{array}{l}\text { Maximum top up from national } \\
\text { resources (Top-up) }\end{array}$ & $30 \%$ & $30 \%$ & $30 \%$ & $30 \%$ & $30 \%$ & $30 \%$ & $30 \%$ \\
\hline Totally & $55 \%$ & $60 \%$ & $65 \%$ & $70 \%$ & $80 \%$ & $90 \%$ & $100 \%$ \\
\hline $\begin{array}{l}\text { Real share of direct payments } \\
\text { in the CR towards the EU average }\end{array}$ & $41 \%$ & $55 \%$ & $63 \%$ & $41 \%$ & $53 \%$ & $59 \%$ & $69 \%$ \\
\hline $\begin{array}{l}\text { Real share of direct payments } \\
\text { in the CR towards the DE average }\end{array}$ & $34 \%$ & $46 \%$ & $49 \%$ & $30 \%$ & $38 \%$ & $43 \%$ & $52 \%$ \\
\hline
\end{tabular}

Source: FADN, own results

Table 5: Conditions for gradual start of direct payments NMS.

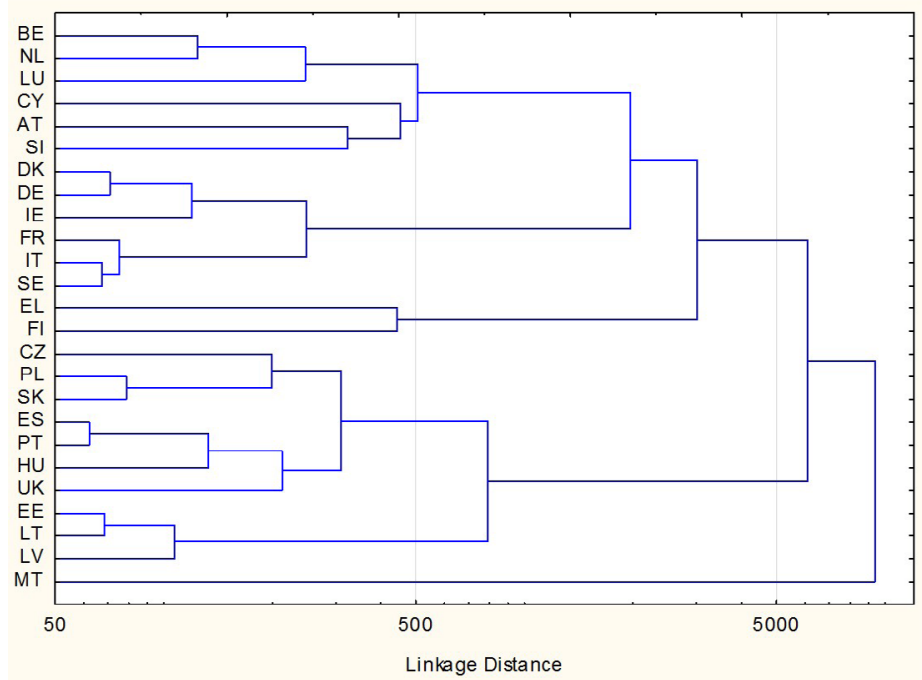

Source: FADN, own results

Figure 2: Dendrogram of EU states according to operational subsidies per ha of utilised agricultural area. 
of the EU average, but the output is below average $(87 \%)$ and costs are $118 \%$ of the EU average.

Group 4 (Spain, Slovakia, Poland, Portugal, Hungary, the UK, the CR) subsidies reach only $254 € /$ ha, which is $76 \%$ of the EU average. The output is $1025 € / \mathrm{ha}$, which is $55 \%$ of the EU and costs are $1188 € /$ ha $(72 \%)$.

Group 5 (Baltic republics - Estonia, Lithuania, Latvia) In this group subsidies reach an average $50 \%$ of the EU subsidies are $167 € /$ ha. Also, the output and costs are significantly below average only $35 \%$ (output) a $40 \%$ (costs) of the EU average.

Group 6 (Malta) In most indicators Malta significantly differs from the EU average. Operational subsidies reach $1976 € /$ ha (594\%), output $12799 € /$ ha and costs $10734 € /$ ha.

The average output in the EU in the monitored period is $1873 € /$ ha and shows an increasing trend. The median shows the average growth rate of $4 \%$ annually. It grew from $1358 € /$ ha in 2004 to $1915 € /$ ha in 2012 with a $17 \%$ slump in 2009 . Output variability was the highest in 2004 (120). It gradually shows a decreasing trend, the lowest being in 2011 (107). The range does not change in time significantly.

In the monitored period the average costs per ha in the EU is $1661 € /$ ha and as well as the output they show an increasing trend in particular years. The median has been growing by $3 \%$ on average since 2004, from $1541 € /$ ha in 2004 to $1938 € /$ ha in 2012. The costs variability is lower than in the output and in particular years it oscillates around 108. The range shows a slightly increasing trend over time. According to the output and costs in particular years of the monitored period, the states can be divided into 6 groups (figure 3 and 4):

Group 1 (Malta, Holland) shows a high output and costs per ha and high operational subsidies per ha of Utilised agricultural area. The average output for the whole monitored period is $1873 € /$ ha in the EU, this group reaches $11273 € /$ ha $=6 \mathrm{x}$ higher. Average costs are $1661 € /$ ha in the EU, this group reaches $10285 € /$ ha $=6.2 \mathrm{x}$ more. The EU average operational subsidies per ha since 2004 are $333 € /$ ha, but they are $621 € /$ ha in this group $=1.9 \mathrm{x}$ more.

Group 2 (Belgium, Cyprus, Denmark) is characterized by above-average ha output (4 $006 € /$ ha) as well as costs (3 $935 € /$ ha) and above-average operational subsidies per ha of Utilised agricultural area. The average output in the monitored period is $2.1 \mathrm{x}$ higher contrary to the EU and average costs are $2.4 \mathrm{x}$ higher. Average operational subsidies are $432 € / \mathrm{ha}=1.3 \mathrm{x}$ higher than the EU average.

Group 3 (Germany, Greece, Italy) the output, costs and subsidies are slightly above the EU average. The output makes $2576 € /$ ha $(1.4 \mathrm{x}$ more than the EU average), costs $2328 € /$ ha (1.4x more than the EU average) and operational subsidies $434 € /$ ha (1.3x more than the EU average).

Group 4 (France, Austria, Luxembourg a Slovenia) the output and costs oscillate around the EU

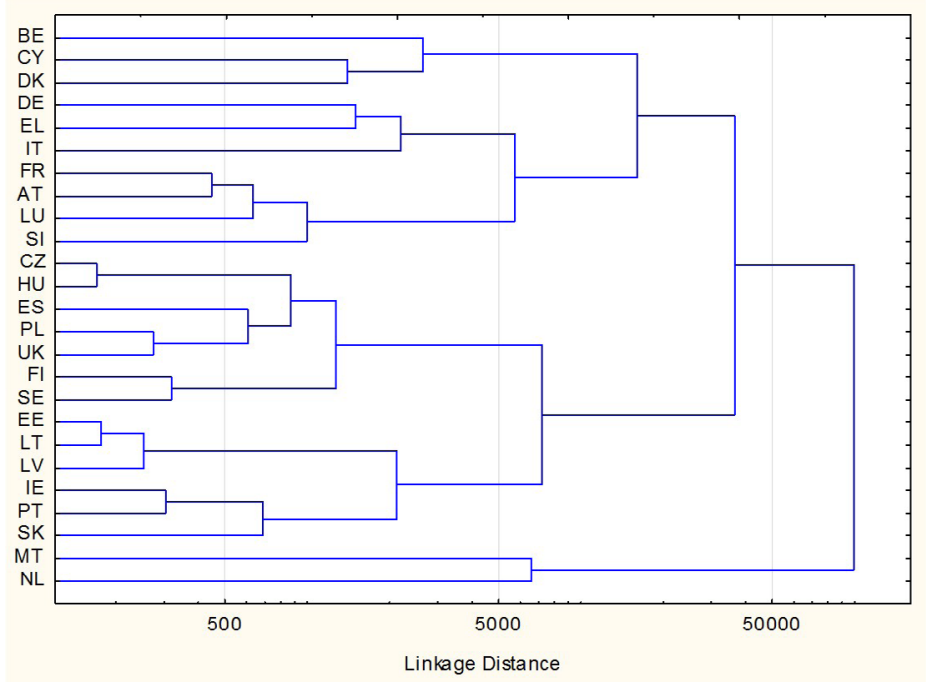

Source: FADN, own results

Figure 3: Dendrogram of EU states according to output per ha of utilised agricultural. 


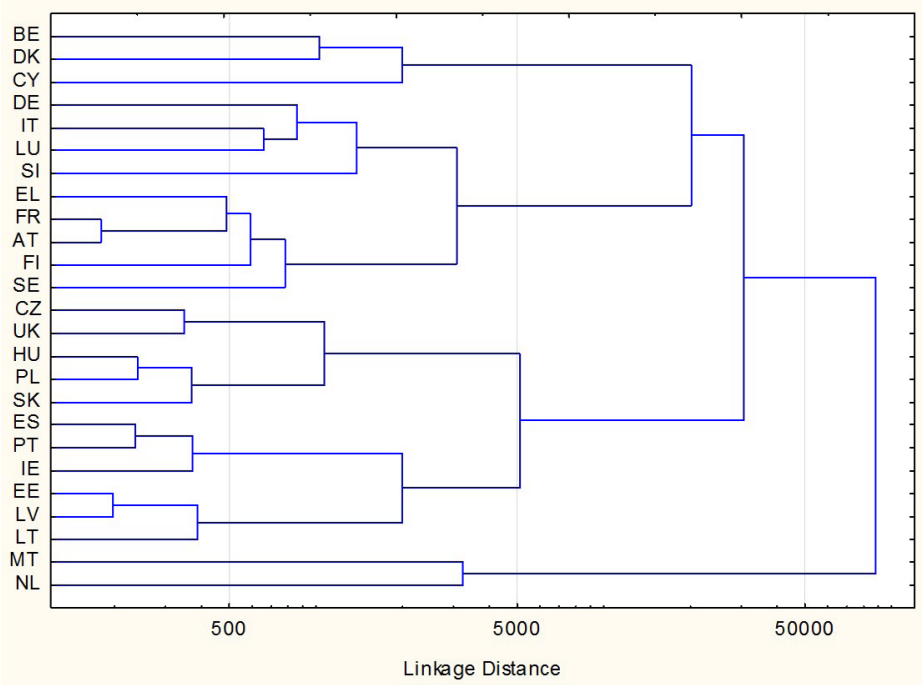

Source: FADN, own results

Figure 4: Dendrogram of EU states according to total costs per ha of utilised agricultural area.

average. The average output makes $1990 € /$ ha (1.1 of the EU average), costs $1991 € /$ ha (121 of the EU average), operational subsidies are $480 € /$ ha $=1.4 \times$ more than the EU average.

Group 5 (the CR, Hungary, Spain; Poland; the UK, Sweden, Finland) the output and costs are below the EU average. Operational subsidies are in average. The average output here is $1314 € /$ ha $(70 \%$ of the EU average), costs $1416 € /$ ha ( $85 \%$ of the EU average) and operational subsidies $343 € /$ ha, i.e. $103 \%$ of the EU average.

Group 6 (Estonia, Lithuania, Latvia, Ireland, Portugal, Slovakia) seems significantly below average as to the extent of output, costs and subsidies. The output reaches only $42 \%$ of the EU average (793 €/ha), costs $59 \%$ (978 €/ha) and subsidies $68 \%(227 € / \mathrm{ha})$.

The relationship of operational subsidies and other derived indices

Table 6 contains correlation coefficients of the relation of operational subsidies and other derived indices. These indices are in the relation:

$\frac{\text { Total outputs }}{\text { Operational subsidies }} \times \frac{\text { Operational subsidies }}{\text { Total inputs }}=\frac{\text { Total outputs }}{\text { Total inputs }}$

Based on the results of the correlation matrix (table 6) the following conclusions can be drawn:

- neither the share of output on subsidies $(r=-0.004)$ nor cost productivity $(r=0.06)$ depend on the extent of operational subsidies

- $\quad$ higher subsidies per ha will occur only very slightly in a higher share of subsidized costs $(r=0.17)$

- the share of output on subsidies influences the cost productivity very slightly $(r=0.24)$

- the share of subsidized costs is in a very slight correlation relation with the cost productivity $(r=-0.06)$

- the share of output on subsidies is in a strong negative dependence on the share of subsidized costs $(r=-0.72)$

Considering the decomposition of above mentioned model, it can be expected multi-collinearity of indicators. The relationship between the share of subsidized costs and output towards subsidies explains non-linear power function (figure 5), where in 2012 the determination index was $I^{2}=0.91$. The highest share of subsidized costs in 2012 shows Finland (0.38) and Greece (0.37; figure 2 group 3), where the output of 2.08 EUR (Finland, or 3.56 Greece) falls on 1 EUR of accepted operational subsidies. Another group is formed by states roughly corresponding with clusters 4 and 5 (figure 2). Here the share of subsidized costs is lower and the output falling on subsidies higher, e.g. the CR's subsidized costs make $22 \%$ and the share of output in subsidies makes 4.09. A lower share of subsidized costs with their higher effectivity is characteristic for states contained in clusters 1 and 2. Parameters of relationship between the share of the subsidized cost and production subsidies remain unchanged in the observed period. 


\begin{tabular}{|l|c|c|c|c|}
\hline Variable & $\begin{array}{c}\text { Operational } \\
\text { subsidies }\end{array}$ & $\begin{array}{c}\text { Total output/ } \\
\text { Operational subsidies }\end{array}$ & $\begin{array}{c}\text { Operational } \\
\text { subsidies / } \\
\text { Total costs }\end{array}$ & $\begin{array}{c}\text { Total output/ } \\
\text { Total costs }\end{array}$ \\
\hline Operational subsidies & 1 & -0.004 & 0.17 & 0.06 \\
\hline Total output / Operational subsidies & -0.004 & 1 & -0.72 & 0.24 \\
\hline Operational subsidies / Total costs & 0.17 & -0.72 & 1 & -0.06 \\
\hline Total output / Total costs & 0.06 & 0.24 & -0.06 & 1 \\
\hline
\end{tabular}

* red marked correlations are significant at $\mathrm{p}<0,05, \mathrm{~N}=237$

Source: FADN, own results

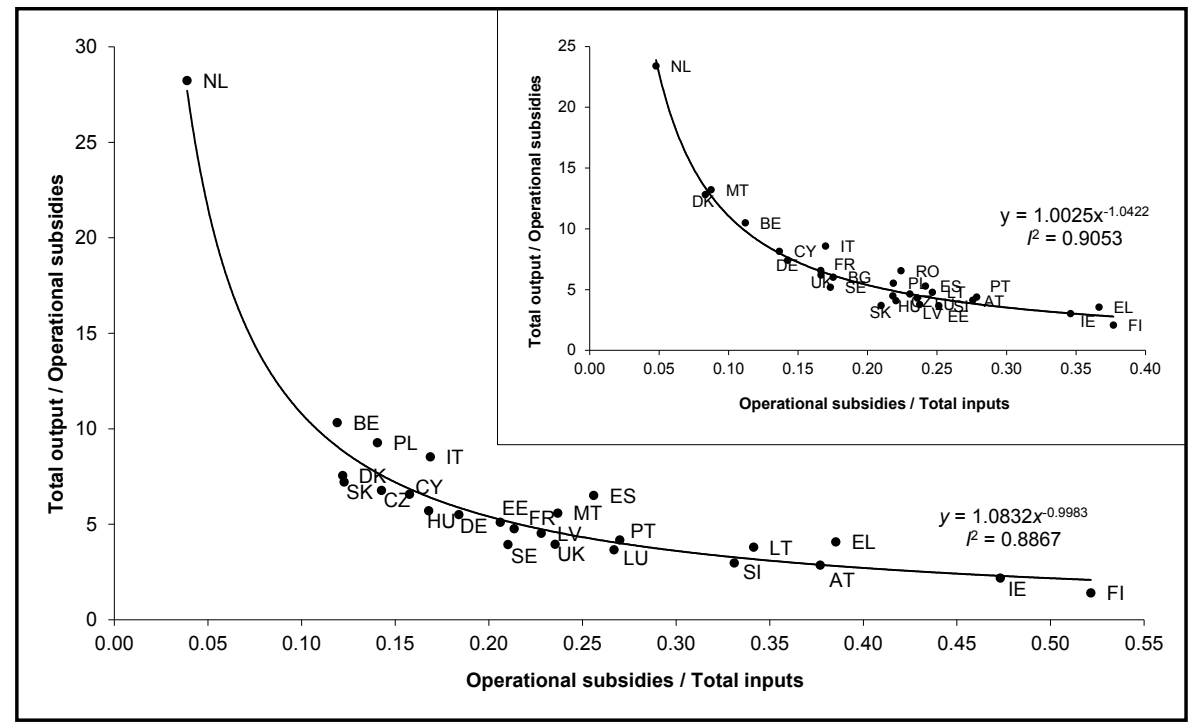

Source: FADN, own results

Figure 5: The relationship between the share of subsidized costs and production in subsidy in 2004 (inserted graph 2012).

\section{Conclusion}

The aim of the article was to analyse operational subsidies in the EU countries. Together with investment subsidies and other possible measures, they are the basis of CAP, which is financed from the EU budget. Although its share in the budget has decreased lately to approx. $40 \%$, it still represents the key EU policy. Using standard output of FADN EU figures in 2004 - 2012 enabled us to draw particular conclusions. The linkage of paid out operational subsidies related to area value of Utilised agricultural area is obvious - the co called decoupling occurs (i.e. breaking away of subsidies from output). It unambiguously implies the diversion from particular crop or animal support (vegetable or animal production), whose share in total operational subsidies dropped on average from about $63 \%$ in 2004 to not quite $8 \%$ in 2012 , in fact the share is converse here, i.e. from about $9 \%$ in 2004 to about $60 \%$ in 2012 .
Comparing the development from 2004, we can see that the area value of an average company increased by more than $10 \%$ in most original member states, in the Baltic countries and Poland (from NMS ). A drop of area value of an average company happened in Slovakia, Cyprus, Hungary, Malta, and the CR, and Slovakia and the CR are countries with the biggest area value of an average farm and also with the biggest share of rented land.

The average extent of subsidy in the EU shifted from $305 € /$ ha in 2004 to $341 € /$ ha in 2012 . Significant differences exist within the EU-27 countries. The median shows an average growth rate of $1 \%$ annually and the variability of subsidies compared to production and costs is the lowest and proves a dropping trend. The subsidy range has a dropping trend over time and the values of minimum and maximum draw near each other during the monitored period. Naturally, in the first years of the EU enlargement new member 
states had a lower starting value, which caught up gradually. Among the least subsidized states both at the beginning and the end of monitoring we can rank Lithuania, Latvia, and Estonia. On the other hand, Malta, Finland, and Greece traditionally rank among the most subsidized states. The biggest growth of operational subsidies in the monitored period happened in Slovakia, the CR, and Poland, yet still neither Slovakia nor Poland reached the EU average. Contrary to 2004, there was a drop in subsidies per ha only in Malta, Austria and the UK. Boháčková and Hrabánková (2011) deal in this context with a question of incomes according to their origin - agricultural incomes, incomes from non-agricultural activities, subsidy means. They state that the representation of subsidies in net entrepreneurial income is very high in some countries (Germany, Austria). A relatively low representation of subsidies is shown in Greece and Spain. The new member countries do not achieve in the net entrepreneurial income such a high percent of subsidies as countries of the former EU-15. A situation in the Czech Republic is characterized by how strong dependence of incomes of agricultural branch on subsidy means is.

Using the cluster analysis, the EU states were divided into several groups. The first group (Belgium, Holland, Luxembourg, Cyprus, Austria and Slovenia) reached the subsidy of $162 \%$ of the EU average. Also the output (222 \%) and costs $(234 \%)$ are significantly above average. On the contrary, Baltic states (Estonia, Lithuania, Latvia) reach operational subsidies of $50 \%$ average of the EU subsidies. Also, the output and costs are significantly below average - at $40 \%$ of the EU average. The only state surpassing the EU average is Malta with subsidies at $594 \%$ of the EU average as well as the output and costs $(600-700 \%)$. This is caused by the higher prices of inputs and outputs and the particularities of agricultural production, e.g. the lowest utilised area value per farm, orientation of production and natural conditions.

The correlation analysis implies that neither the share of subsidies in production nor the productivity defined as the share of costs in production depends on the extent of operational subsidies. Increasing subsidies per ha of Utilised agricultural area will not occur in a higher productivity of costs and only very slightly it will occur in a higher share of subsidized costs. The share of output in subsidies influences the productivity of costs very slightly and the share of production in subsidies is in a strong negative dependence on the share of subsidized costs. The highest share of subsidized costs in 2012 shows Finland and Greece, another group is formed by states Spain, Slovakia, Poland, Portugal, Hungary, the UK, the CR and Baltic republics. Here the share of subsidized costs is lower and the output falling on subsidies higher. A lower share of subsidized costs with their higher effectivity is characteristic for states Belgium, Holland, Luxembourg, Cyprus, Austria, Slovenia, France, Sweden, Italy, Denmark, Germany and Ireland. Similar results appear in article Giannakis and Bruggeman (2015). They say that high performing countries are mainly located in the Northern-Central part of the EU, while the continental peripheries make up the low performing cluster. Their results indicate that there is a statistically significant relationship between the high performing countries and the direct CAP payments per farm holding. This wide variation of support levels deteriorates further the performance of farm sectors with chronic structural weaknesses. The redistribution of direct payments between old and new member states after 2013 aims to close by one third the gap between current level and $90 \%$ of EU average by 2020 . This evolution will put new pressures on countries receiving direct per hectare payments significantly over the EU average.

\section{Acknowledgements}

The authors thank the Ministry of Education of the Czech Republic for financial support, Research Program of the Department of Accounting and Finance (RVO160).

\author{
Corresponding author: \\ Ing. Jana Lososová \\ Department of Finance and Accounting, Faculty of Economic, \\ University of South Bohemia in České Budějovice \\ Studentská 13, 37005 České Budějovice, Czech Republic \\ E-mail:lososova@ef.jcu.cz
}




\section{References}

[1] Acs, S., Hanley, N., Dallimer, M., Gaston, K. J., Robertson, P., Wilson, P, Armsworth, P. R. The effect of decoupling on marginal agricultural systems: Implications for farm incomes, land use and upland ecology. Land Use Policy. 2010, Vol. 27, No.2, p. 550-563. ISSN 0264-8377.

[2] Beard, N., Swinbank, A. Decoupled payments to facilitate CAP reform. Food Policy. 2001, Vol. 26, No. 2, p. 121-145. ISSN 0306-9192.

[3] Bečvářová, V., Sadílek, T., Vinohradský, K., Zdráhal, I. Vývoj českého zemědělství v evropském kontextu. Brno: MZLU in Brno. 2008, 64 p. ISBN 978-80-7375-255-2.

[4] Benjamin, C., Le Roux, Y., Phimister, E. Direct payments versus interest rate subsidies to new farmers: a simulation analysis of alternative farm set-up policies in France. Land Use Policy. 2006, Vol. 23, No. 3, p. 311-322. ISSN 0264-8377.

[5] Boháčková, I., Hrabánková, M. Influence of subsidies on height and structures of farmers' incomes in EU member states. Agris on-Line Papers in Economics and Informatics, 2011, Vol. 3, No. 3, p. 29-43. ISSN 1804-1930.

[6] Ciaian, P., Kancs, D., Swinnen, J. F. M. The impact of the 2013 reform of the common agricultural policy on land capitalization in the european union. Applied Economic Perspectives and Policy. 2014, Vol. 36, No. 4, p. 643-673. ISSN 2040-5790.

[7] Ciaian, P., Pokrivčák, J., Bartová, L., Drabik, D. The impact of the CAP reform and exchange rates on Slovak agriculture. Agric. Econom. - Czech. 2007, Vol. 53, No. 3, p. 111-122. ISSN 0139-570X.

[8] Donaldson, A. B., Flichman, G., Webster, J. P. G. Integrating Agronomic and Economic Models for Policy Analysis at the Farm Level: the Impact of CAP Reform in Two European Regions. Agricultural Systems. 1995, Vol. 48, No. 2, p. 163-178. ISSN 0308-521X.

[9] Erjavec, K., Erjavec, E. 'Greening the CAP' - just a fashionable justification? A discourse analysis of the 2014-2020 CAP reform documents. Food Policy. 2015, Vol. 51, p. 53-62. ISSN 0306-9192.

[10] European Commission. Agriculture. A partnership between Europe and farmers, DirectorateGeneral for Communication. 2014, p. 16. ISBN: 978-92-79-37537-8.

[11] European Commission. CAP reform - basic Regulations. 2013. [on-line]. Available: http://ec.europa. eu/agriculture/cap-post-2013/legislation/index_en.htm [Accessed: 11 June 2015].

[12] Fárek, J., Foltýn, J. Developing countries in economic globalization era. Politická ekonomie. 2004, Vol. 52, No. 6, p. 793-806. ISSN 0032-3233.

[13] Garzon, I. Reforming the Common Agricultural Policy. August 2006. [Online] Available: http://www.palgraveconnect.com/pc/doifinder/10.1057/9780230626577 [Accessed: 25 May 2015].

[14] Giannakis, E., Bruggeman, A. The highly variable economic performance of European agriculture. Land Use Policy. 2015, Vol. 45, p. 26-35. ISSN 0264-8377.

[15] Grega, L. Ekonomická opodstatněnost podpory zemědělství. 2005, $1^{\text {st }}$ ed. Brno: Mendel University in Brno, Faculty of Economics and management. ISBN 80-715-7829-0.

[16] Latruffe, L., Davidova, S. Common Agricultural Policy direct payments and distributional conflicts over rented land within corporate farms in the New Member States. Land Use Policy. 2007, Vol. 24, No. 2, p. 451-457. ISSN 0264-8377.

[17] Lososová, J., Zdeněk, R., Kopta, D. Differences in the land rent between EU countries. Acta univ. agric. et silvic. Mendel. Brun., 2013, Vol. LXI, No. 7, p. 2435 - 2444. ISSN 1211-8516.

[18] Moyer, H. W., Josling, T.E. Agricultural policy reform. Politics and Process in the EU and US in the 1990s. Ashgate, Aldershot. 2002. ISBN 0-7546-3050-1.

[19] Offermann, F., Nieberg, H., Zander, K. Dependency of organic farms on direct payments in selected EU member states: Today and tomorrow. Food Policy. 2009, Vol. 34, No.3, p. 273-279. ISSN 0306-9192. 
[20] Pokrivčák, J., Svinnen, J. F. M., Gorter, H. Agricultural policy and european integration. Journal of Economics. 2003, Vol. 51, No. 1, p. 33-49. ISSN 0013-3035.

[21] Rencher, A. C. Methods of Multivariate Analysis, 2 ${ }^{\text {nd }}$ ed. Hoboken: Wiley. 2002. ISBN 0-471-41889-7.

[22] Řezanková, H., Húsek, D., Snášel, V. Shluková analýza dat. $2^{\text {nd }}$ ed. Praha: Professional Publishing. 2009. ISBN 978-80-86946-81-8.

[23] Svatoš, M. Ekonomika zemědělství a evropská integrace. $4^{\text {th }}$ ed. Prague: Czech University of Life Sciences Prague. 1999. 266 p. ISBN 80-213-0439-1.

[24] Swinnen, J. F. The political economy of agricultural and food policies: Recent contributions, new insights, and areas for further research. Applied Economic Perspectives and Policy. 2010, Vol. 32, No. 1, p. 33-58. ISSN 2040-5790.

[25] Szabo, L., Grznár, M. Subsidies and efficiency in the agricultural sector. Journal of Economics. 2002, Vol. 50, No. 6, p. 971-988. ISSN 0013-3035.

[26] The Farm Accountancy Data Network (FADN). Standard results. 2015. [on-line]. Available: http://ec.europa.eu/agriculture/rica/database/consult_std_reports_en.cfm [Accessed: 27 March 2015].

[27] Uthes, S., Piorr, A., Zander, P., Bienkowski, J., Ungaro, F., Dalgaard, T., Stolze, M., Moschitz, H., Schader, Ch., Happe, K., Sahrbacher, A., Damgaard, M., Toussaint, V., Sattler, C., Reinhardt, F-J., Kjeldsen, Ch., Casini, L., Müller, K. Regional impacts of abolishing direct payments: An integrated analysis in four European regions. Agricultural Systems. 2011, Vol. 104, No. 2, p. 110-121. ISSN 0308-521X.

[28] Van Beers, C., Van den Bergh, J. C. J. M. Perseverance of perverse subsidies and their impact on trade and environment. Ecological Economics. 2001, Vol. 36, No. 3, p. 475-486. ISSN 0921-8009.

[29] Zdeněk, R., Lososová, J., Kopta, D. Land rent development in the period 2011 - 2013. In: Proceedings of the $8^{\text {th }}$ International Scientific Conference INPROFORUM Investment Decision-Making in the Period of Economic Recovery. 2014, p. 103 - 108. ISBN 978-80-7394-484-1. 